J. Perinat. Med. $11(1983) 193$

\section{Colloid osmotic pressure: Variations in normal pregnancy}

\author{
P. Y. K. Wu, V. Udani, L. Chan, F.C. Miller, C. E. Henneman
}

Departments of Pediatrics (Neonatology Division), Family and Preventive Medicine, and Obstetrics and Gynecology, University of Southern California School of Medicine, Los Angeles County-USC Medical Center and the H. Claude Hudson Comprehensive Health Center, Los Angeles, USA

\section{Introduction}

Pregnancy is associated with changes in both the volume [10] and composition [2] of fluid in body water compartments. During normal pregnancy, there is an increase in fluid volume in the intravascular $[5,6]$ and the extravascular compartments [7]. The mechanism of water retention in the extravascular compartment, of about two liters, [3] is not fully understood. The forces which regulate movement across capillary membrane were first elucidated by STARLING [8]. The direction of flow of fluid between vascular and interstitial spaces depends on the balance of forces due to: (I) Capillary hydrostatic pressure, (II) concentration of serum proteins (oncotic pressure), (III) tissue tension, and (IV) lymph flow. Thus increased fluid passage into the extravascular space may occur during pregnancy when the intra-capillary hydrostatic pressure exceeds the opposing influence of plasma colloid osmotic pressure (COP). Studies by ROBERTSON et al. [7] suggest that the development of edema while not related to fall in total osmolality, is related to the degree of the fall in COP during pregnancy. Direct measurements of COP are accurate and easily obtainable by a membrane osmometer. This approach should help to elucidate the forces governing fluid flux during pregnancy.

This study was undertaken to determine the changes in COP with gestational age that occur during normal pregnancy. The relationships

\section{Curriculum vitae}

PAUL Y. K. WU, M.D. received his undergraduate training at The Medical College Universtiy of Calcutta, India. He was trained in Pediatrics at the Queen Elizabeth's Hospital For Children, London, U.K. He first received training in Neonatology at the Dr. Mary Crosse Premature Baby and Special Care Unit, Birmingham, U.K. and subsequently at The Michael Reese Hospital, Chigaco, U.S. He joined the faculty of the University of Southern California School of Medicine in the Division of Neonatology of the Department of Pediatrics in 1969. He is currently Professor of Pediatrics and Associate Director of the Neonatology Division. His research interests are in the area of body water homeostasis, macro-micro circulation, nutrition, bilirubin metabolism and phototherapy.

of COP with hematocrit (HCT), serum total solid (STS), mean blood pressure (MBP), and MBP-COP gradient were also investigated.

\section{Patients and methods}

\subsection{Patients}

Normal pregnant women receiving prenatal care at the Los Angeles County-University of Southern California Medical Center and at the H. Claude 


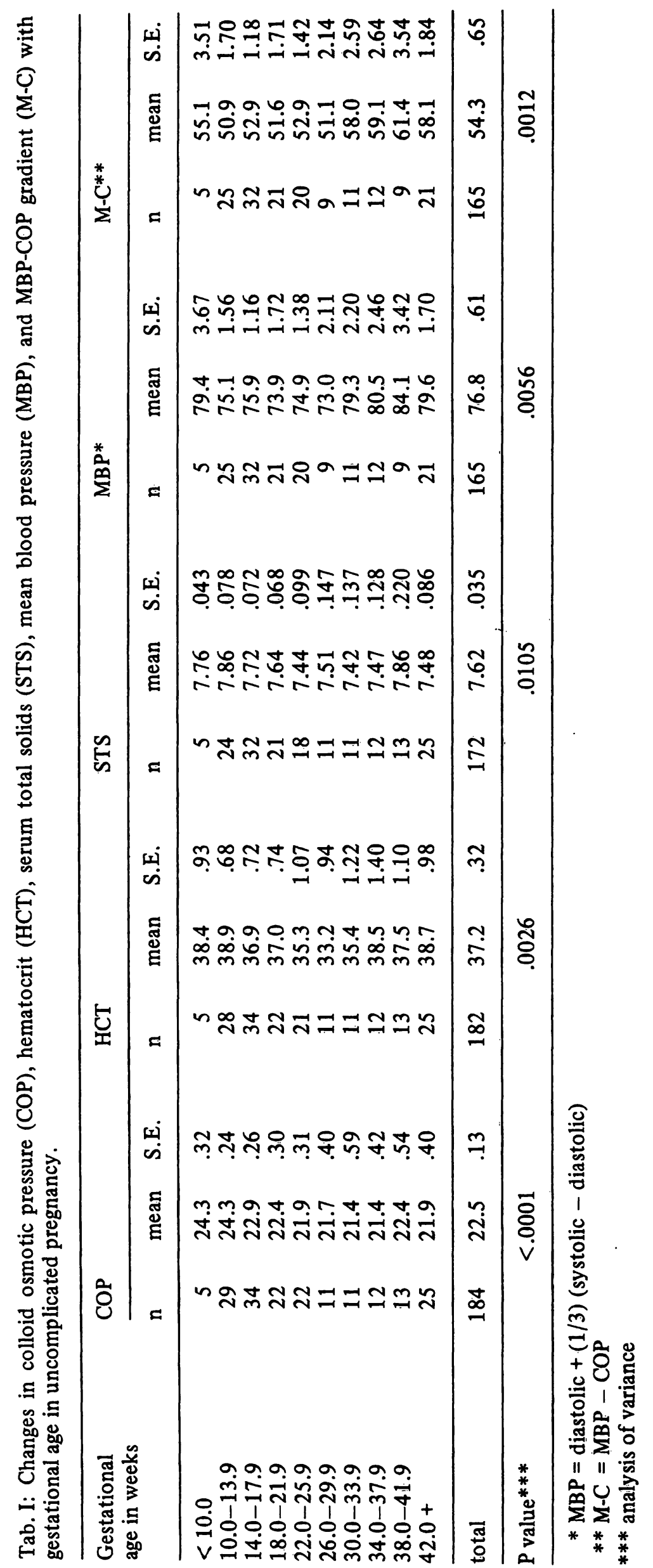


Hudson Comprehensive Health Center from September 1980 through June 1981 were included in the study.

Pregnancy dating was based primarily upon the patients history of her last menstrual period. Patients with discrepancy between their LMP and clinical assessment of gestational age, based on early examination of uterine growth, and/or ultrasound were excluded from this study.

Blood was drawn in a heparinized vacutainer tube by venepuncture. The COP was measured by using a WESCOR COLLOID OSMOMETER (Model 4100) as previously described by WU et al. [11]. This osmometer uses a semipermeable membrane (Amicon PM30) to separate the reference chamber of normal saline from the sample chamber. Introduction of an oncotically active solution into the sample chamber causes a flux of water across the membrane into the chamber. The resulting pressure gradient reflect the COP of the sample solution and is measured by a transducer. Digital readout was obtained after one to two minute equilibration period. Reproducibility of duplicates was within $\pm 0.3 \mathrm{mmHg}$. The osmometer was calibrated daily against reconstituted standards (human alubmin) supplied by WESCOR, Inc. Hematocrit was obtained by filling a microcapillary tube with blood and centrifuged at 10,000 RPM for 5 minutes with a microcentrifuge. Serum total solids was determined by using the supernatent serum from the hematocrit microcapillary tube in a Total Solid (TS) Meter (AMERICAN OPTICAL SCIENTIFIC INSTRUMENT SERVIS, Bufallo, N.Y.). The brachial blood pressure was measured with a sphygomomanometer in a sitting position.

\subsection{Statistical analysis}

The relationship of COP with gestational age, as well as its relationship with blood hematocrit (HCT), serum total solids (STS), mean blood pressure (MBP) and MBP-COP gradient (M-C) was studied using analysis of variance and correlation analysis. Mean blood pressure (MBP) was defined as the sum of diastolic blood pressure (DBP) and one-third the difference of systolic (SBP) and diastolic blood pressures [DBP + (1/3 (SBP-DBP)], and MBP-COP gradient is defined as the difference between MBP and COP. Since the two major forces which determine the flux of fluid between intra and extravascular spaces are hydrostatic pressure (BP) and COP, the gradient between MBP and COP provides an indication of the changes in the forces governing this flux. The stepwise multiple regression analysis was performed to determine the degree of correlation of COP with these variables.

The relationship of COP and gestational age was further examined by fitting higher degree polynomials [2]. Analysis of covariance was used to test for statistical differences of the curves.

\section{Results}

3.1 The COP fell gradually during the first and second trimesters and reached its lowest level between the 30-40 weeks of gestation (Tab. I).

Thereafter it rose slightly with advancing gestational age. Analysis of variance showed that this pattern of change in COP during pregnancy was significant at $P<.0001$. The quadratic equation was found to be the best fit to the data describing the relationship of COP and gestational age (Fig. 1). The quadratic equation improved the

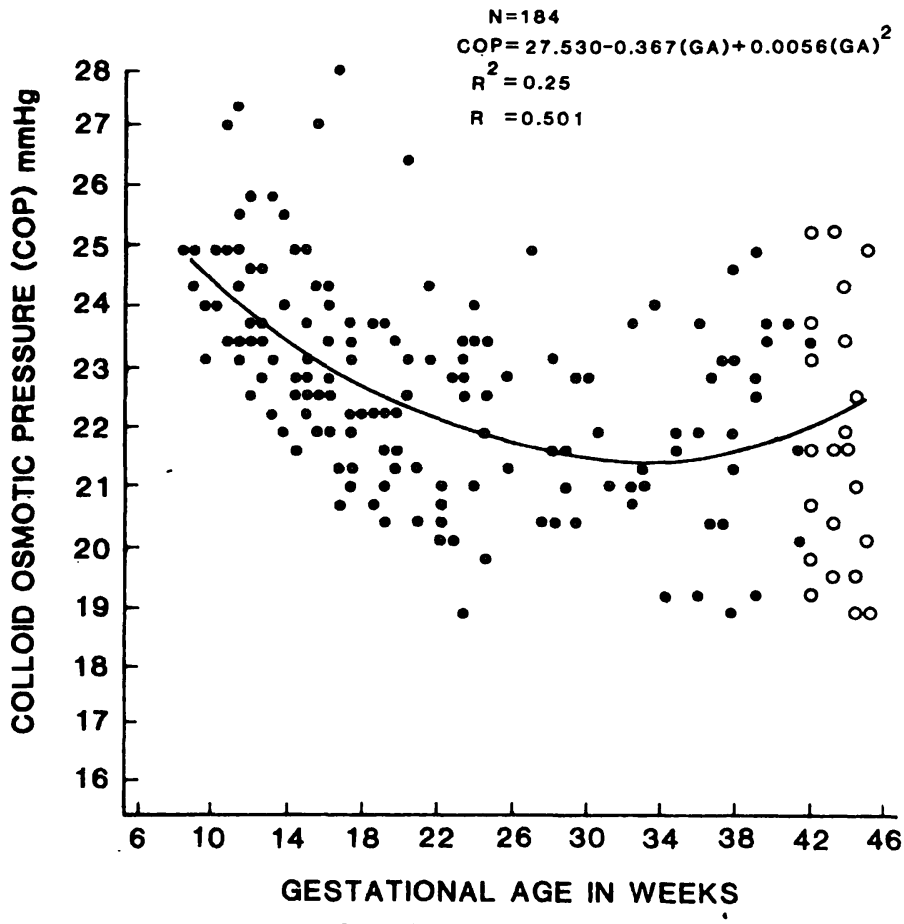

Fig. 1. Correlation of colloid osmotic pressure (COP) of whole blood and gestational age (GA) in women with uncomplicated pregnancy. $(\bullet)$ denotes first, second and third trimester, $(0)$ denotes post-term pregnancy. 
Tab. II. Linear and quadratic relationships of colloid osmotic pressure (COP), hematocrit (HCT), serum total solids (STS), mean blood pressure (MBP), and MBP-COP gradient (M-C) with gestational age (GA) in uncomplicated pregnancy.

\begin{tabular}{|c|c|c|c|c|c|c|c|c|}
\hline \multirow[b]{2}{*}{$\begin{array}{l}\text { Dependent } \\
\text { variable }\end{array}$} & \multirow[b]{2}{*}{$\begin{array}{l}\text { Independent } \\
\text { variable }\end{array}$} & \multirow[b]{2}{*}{$\begin{array}{l}\text { Number } \\
\text { of cases }\end{array}$} & \multicolumn{3}{|l|}{ Linear } & \multicolumn{3}{|l|}{ Quadratic } \\
\hline & & & $\begin{array}{l}\text { Correlation } \\
\text { coefficient }\end{array}$ & $\begin{array}{l}\text { Goodness } \\
\text { of fit }\end{array}$ & $\begin{array}{l}\text { Signifi- } \\
\text { cance of } r\end{array}$ & $\begin{array}{l}\text { Correlation } \\
\text { coefficient }\end{array}$ & $\begin{array}{l}\text { Goodness } \\
\text { of fit }\end{array}$ & $\begin{array}{l}\text { Signifi- } \\
\text { cance of } \\
\text { gain in } r^{2}\end{array}$ \\
\hline $\mathbf{Y}$ & $\mathrm{X}$ & $\mathrm{n}$ & $\mathbf{r}$ & $r^{2}$ & $t$ test $^{+}$ & $\mathbf{r}$ & $\mathbf{r}^{2}$ & $\bar{F}$ test $^{++}$ \\
\hline COP & GA & 184 & -.395 & .156 & $* *$ & .501 & .251 & $* *$ \\
\hline $\mathrm{HCT}$ & GA & 182 & .006 & .000 & -- & .274 & .075 & $* *$ \\
\hline STS & GA & 172 & -.191 & .036 & $*$ & .241 & .058 & $*$ \\
\hline MBP & GA & 165 & .248 & .062 & $* *$ & .265 & .070 & -- \\
\hline M-C & GA & 165 & .326 & .106 & $* *$ & .327 & .107 & -- \\
\hline
\end{tabular}

+ The test statistic is $\mathrm{t}=\frac{\sqrt{\mathrm{n}-2 \mathrm{r}}}{\sqrt{1-\mathrm{r}^{2}}} . \quad * *$ indicates significance at .01 level; $\quad *$ indicates significance at .05 level; and - indicates non-significanc.

++ The numerator sum of squares for each $F$ test is the sum of squares attributed to all orthogonal polynomials of higer degree (in this case, it is the second degree) and the denominator sum of squares is the residual sum of squares from the fit to the highest degree polynomial. The $F$ test is performed in BMDP packaged program P5R. Indications of significance are the same as above.

linear relationship from a measure of goodness of fit of $15.6 \%$ to $25.1 \%$ (Tab. II).

Higher degrees of regression polynomial were not found to provide significant gain in the goodness of fit.

3.2 The hematocrit and serum total solids similarly fell gradually during the first and second trimesters, and reached the lowest levels between 26-30 weeks of gestation respectively (Tab. I). Thereafter it rose with advancing gestational age. Analysis of variance showed that these changes in HCT and STS during pregnancy were also significant at $\mathrm{P}=.0026$ and $\mathrm{P}=.0105$ respectively. It is interesting to note in Tab. II that the quadratic curve was found to contribute significant gain to describe the relationship of HCT and GA and of STS and GA. (Fig. 2 presents the plot and the quadratic curve of STS with gestational age.

3.3 The mean blood pressure also fell gradually during the first and second trimesters and was lowest between 26-30 weeks of gestation. The changes were significant at $\mathrm{P}<.006$. The gradient MBP and COP showed a somewhat irregular pattern in the early course of the pregnancy but showed a definite increase in the gradient during the last trimester of the pregnancy (Tab. I). Both MBP and M-C gradient were found to be linearly related to gestational age and the quadratic curves did not add significant improvement to describe their relationships (Tab. II).

3.4 Further comparisons were made on the correlation of COP and STS, HCT, MBP and M-C gradient (Tab. III).

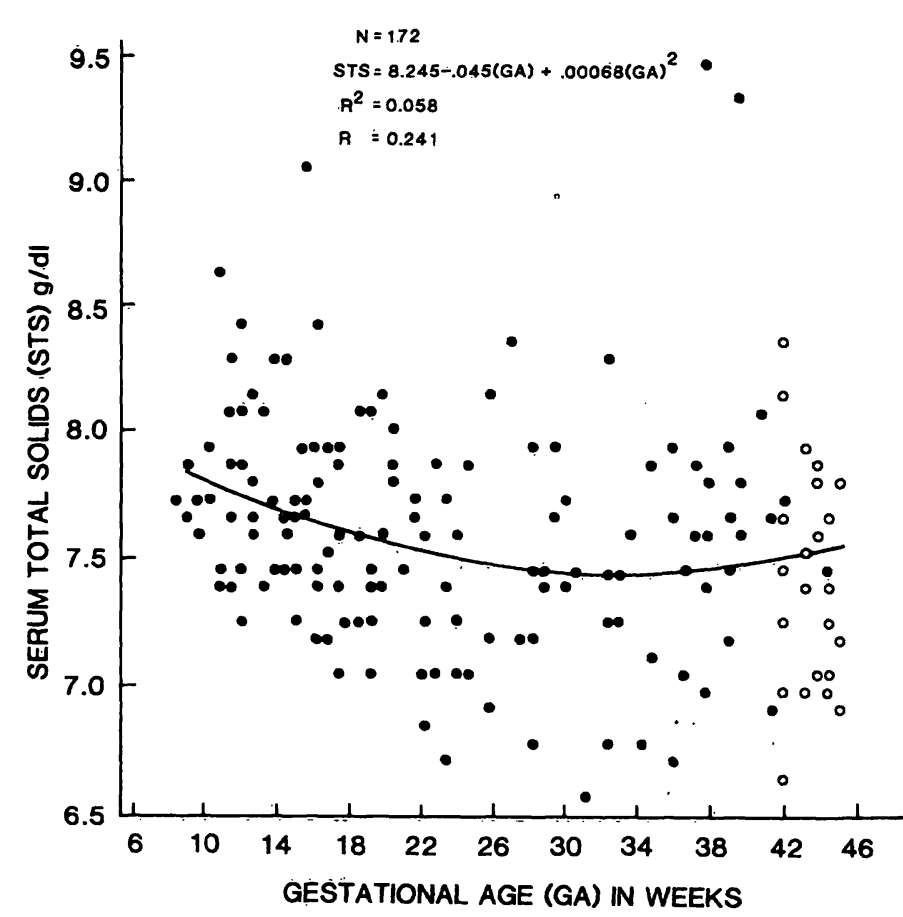

Fig. 2. Correlation of serum total solids (STS) and gestational age (GA) in women with uncomplicated pregnancy, $(\bullet)$ denotes first, second and third trimester. (O) denotes post-term pregnancy. 
Tab. III. Linear relationship of colloid Osmotic pressure (COP) with hematocrit (HCT), serum total solids (STS), mean blood pressure (MBP), and MBP-COP gradient (M-C) in uncomplicated pregnancy.

\begin{tabular}{|c|c|c|c|c|c|}
\hline \multicolumn{6}{|c|}{ Uncomplicated Pregnancy } \\
\hline $\begin{array}{l}\text { Dependent } \\
\text { variable } \\
\text { Y }\end{array}$ & $\begin{array}{l}\text { Independent } \\
\text { variable } \\
\mathrm{X}\end{array}$ & $\begin{array}{l}\text { Number } \\
\text { of cases } \\
n\end{array}$ & $\begin{array}{l}\text { Correlation } \\
\text { coefficient } \\
r\end{array}$ & $\begin{array}{l}\text { Goodness } \\
\text { of fit } \\
r^{2}\end{array}$ & $\begin{array}{l}\text { Significance of } \\
t \text { Test }^{+} r\end{array}$ \\
\hline $\begin{array}{l}\text { COP } \\
\text { COP } \\
\text { COP } \\
\text { COP }\end{array}$ & $\begin{array}{l}\text { STS } \\
\text { HCT } \\
\text { MBP } \\
\text { M-C }\end{array}$ & $\begin{array}{l}176 \\
186 \\
168 \\
168\end{array}$ & $\begin{array}{r}.708 \\
.168 \\
-.179 \\
-.383\end{array}$ & $\begin{array}{l}.501 \\
.028 \\
.032 \\
.147\end{array}$ & $\begin{array}{l}* * \\
* \\
* \\
* *\end{array}$ \\
\hline
\end{tabular}

+ Same as in Tab.II.

COP and STS were found to be highly correlated $(\mathrm{P}<.01$, Fig. 3). COP was found to be correlated with HCT and MBP only at marginal levels (correlation coefficient $<0.2$ ). COP was strongly negatively correlated with $\mathrm{M}-\mathrm{C}$ gradient $(\mathrm{P}<.001)$. The stepwise multiple regression analysis of COP on GA, STS, HCT, MBP and M-C showed that STS was the most significant variable with GA, M-C gradient and MBP following in order. With the exclusion of HCT, the variables explained $100.0 \%$ of the variation of COP.

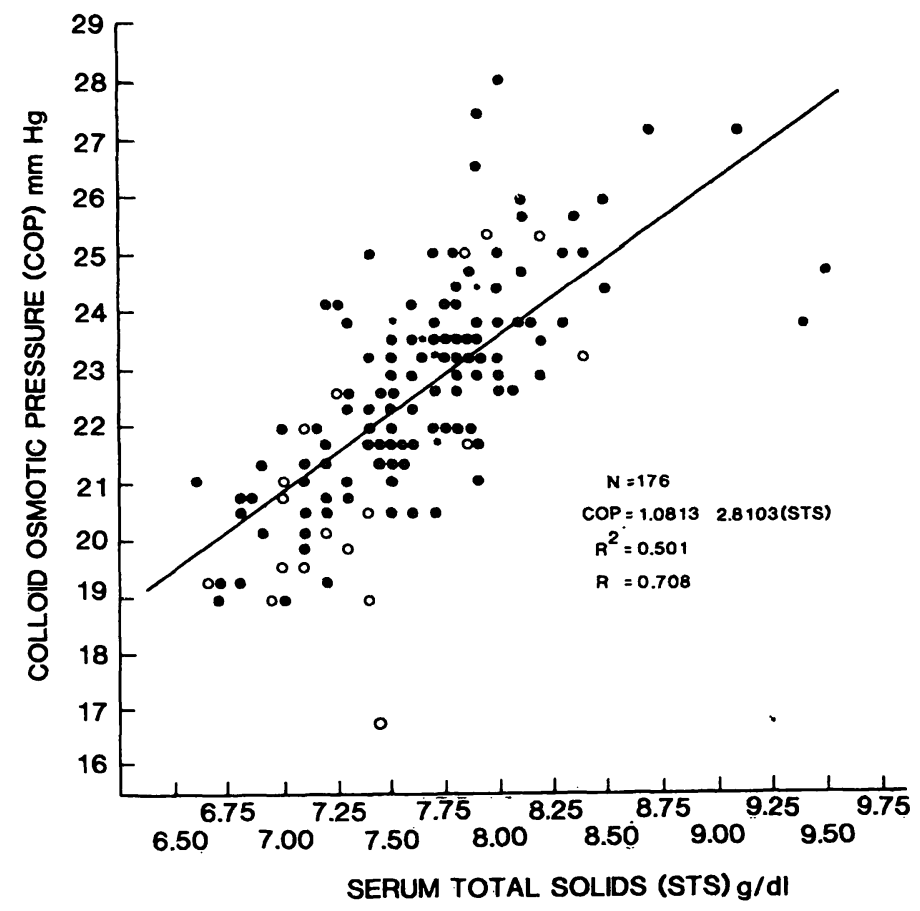

Fig. 3. Linear correlation of colloid osmotic pressure (COP) and serum total solids (STS) in uncomplicated pregnancy.

\section{Discussion}

The role of colloid osmotic pressure in regulating fluid flux across capillary membrane is well recognized. The recent development of the electronic pressure transducer for direct measurement of COP has made serial measurements of COP readily available for clinical use, such as its uses as a guide to fluid selection when replacement is required, or for the early detection of pulmonary edema. Although pregnancy is known to be associated with fluid shifts between the intravascular and interstitial spaces $[9,10]$, there is currently minimal data on the variation of COP during pregnancy.

Plasma volume increases steadily during pregnancy, achieving its peak at 34 weeks then it plateaus until term $[5,6]$. Some investigators found a decrease in plasma volume after 34-36 weeks of gestation [1]. However, this was probably due to impaired venous return from compression of the inferior vena cava by the gravid uterus, since these women were studied in the supine position. Pregnant women studied in the lateral position did not exhibit this terminal fall in plasma volume [6]. Overall there is an increase in plasma volume during pregnancy $[4,10]$. Although the results from the present study do not explain the rise in plasma volume during pregnancy, nevertheless, this increment in plasma volume may account, at least in part, for a fall in COP if there is no corresponding rise in colloids.

Red cell volume also increased progressively during pregnancy but to a lesser extent than plasma volume, leading to a fall in the hematocrit. This 
process is reflected in the fall in HCT during the first and second trimester in our women with normal pregnancy.

The COP is determined by the concentration of plasma proteins. Because of the cost and time involved in laboratory determination of serum proteins and albumin, they are less applicable for rapid clinical use than direct measurements of COP. STS is easily obtainable at bedside. Since the principal component of STS is albumin, changes in STS levels will reflect changes in serum albumin concentration. Our finding that STS fell during pregnancy to its lowest level at 30-34 weeks gestation and then rose toward term is in agreement with changes in serum albumin during pregnancy found in previous studies [4,9]. The parallel changes of COP and STS during pregnancy are consistent with the finding that COP correlated positively with STS.

According to STARLING's hypothesis, the net driving pressure (NDP) for fluid flux across the capillary membrane is the algebraic sum of opposing hydrostatic and colloid osmotic pressures across the capillaries. Thus the major component of the NDP (represented by the M-C gradient) with advancing gestation, would be expected to cause a greater shift of fluid out of the intravascular compartment leading to an expansion of the extravascular compartment. The balance between the $\mathrm{M}-\mathrm{C}$ gradient and the opposing tissue tension will determine the extent of the extravascular fluid expansion. The fact that the present studies showed that M-C rose in the latter part of gestation suggests that one of the mechanisms involved in the expansion in extravascular fluid volume during this period $[3,7]$ may be related to this rise in the M-C. Although the forces determining the net flux of fluid between body water compartments will vary in different parts of the body; nevertheless the M-C do provide an indication of the overall direction of changes that may occur in the body. Further study of the changes in COP will help to elucidate alterations in body water found in pregnancies complicated by hypertension, toxemia and diabetes mellitus. Sequential changes in COP may serve as one of the indicators of responses to therapy.

\section{Summary}

Pregnancy is associated with an increase in the extravascular fluid by about two litres. The regulation of fluid flux across capillary membrane is dependent on the STARLING's forces. Thus increased fluid shift into the extravascular space may occur during pregnancy when the intra-capillary hydrostatic pressure exceeds the opposing influence of plasma colloid oncotic pressure (COP). In order to evaluate these forces more fully, COP, hematocrit (HCT), serum total solids (STS), mean blood pressure (MBP) and MBP-COP gradient (M-C) were measured cross-sectionally in 184 women with normal uncomplicated pregnancy. COP fell gradually during the first and second trimesters, lowest at 30-34 weeks, thereafter it rose. The relationship of COP and gestational age was best described by the quadratic equation. The patterns of changes of HCT and STS with respect to gestational age were similar to COP. MBP and $\mathrm{M}-\mathrm{C}$ were linearly correlated to gestational age. The increment in M-C with advancing gestational age would promote fluid flux from intra to extravascular space in normal pregnancy.

Keywords: Colloid osmotic pressure (COP), MBP-COP gradient, mean blood pressure (MBP), serum total solids (STS).

\section{Zusammenfassung}

Veränderungen des kolloidosmotischen Druckes in der normalen Schwangerschaft

Die Schwangerschaft geht mit einer Zunahme der extravasalen Flüssigkeit um etwa 2 Liter einher. Die Regulation des Flüssigkeitstransportes über die Kapillarmembran ist abhängig von den STARLING'schen Kräften. So könnte eine Zunahme des Flüssigkeitstransportes in den Extravasalraum erfolgen, wenn der intrakapilläre hydrostatische Druck die entgegengerichtete Wirkung des kolloidosmo-

tischen Drucks im Plasma übersteigt. Um diese Vorgänge genauer $\mathrm{zu}$ untersuchen, haben wir bei 184 zufällig ausgewählten Frauen mit unkompliziertem Schwangerschaftsverlauf den kolloidosmotischen Druck, den Hämatokrit, die Gesamtmenge an Feststoffen im Serum, den mittleren Blutdruck sowie den Gradienten zwischen mittlerem Blutdruck und kolloidosmotischen Druck bestimmt. Der kolloidosmotische Druck zeigte einen allmählichen Abfall während des ersten und zweiten 
Trimesters mit einem Minimum in der 30.-34. Woche; danach erfolgte ein Anstieg. Das Verhältnis von kolloidosmotischem Druck und Schwangerschaftswoche läßt sich am besten durch eine quadratische Gleichung beschreiben. Der Hämatokrit und die Gesamtmenge an Feststoffen im Serum verhielten sich bezogen auf die Schwangerschaftswoche ähnlich wie der kolloidosmotische Druck. Der mittlere Blutdruck und der Gradient zwischen mittlerem Druck und kolloidosmotischen Druck zeigten eine lineare Korrelation mit der Schwangerschaftswoche. Die Zunahme des Gradienten zwischen mittlerem Blutdruck und kolloidosmotischen Druck könnte eine Flïssigkeitsverschiebung vom Intravasalin den Extravasalraum bei normalen Schwangerschaften begünstigen.

Schlüsselwörter: Gesamtmenge an Feststoffen im Serum, Gradient zwischen mittlerem Bludruck und kolloidosmotischen Druck, kolloidosmotischer Druck, mittlerer Blutdruck.

\section{Résumé}

Pression osmotique colloïde = Variations au cours de la grossesse normale.

La grossesse s'accompagne d'une augmentation des liquides extravasculaires d'environ 2 Litres. La régulation des flux liquidiens à travers la membrane capillaire est sous la dépendance des forces de STARLING. Ainsi, les modifications liquidienne dans l'espace extravasculaire peuvent se produire pendant la grossesse lorsque la pression hydrostatique intra-capillaire dépasse l'influence opposée de la pression oncotique colloide plasmique (P.O.C.). Afin d'évaluer ces forces plus complètement, la POC, l'hématocrite (HTC), les protéines sériques totales (PST), la pression sanguine moyenne (PSM) et la gradient
PSM-POC (PP) ont été déterminés chez 184 femmes présentant une grossesse normale non compliquée. La POC chute progressivement au cours du premier et du deuxième trimestre, avec un minimum à $30 / 34$ semaines, ensuite elle remonte. La relation entre la $\mathrm{POC}$ et l'âge gestationnel a été décrite au mieux par l'équation quadratique. Les niveaux de variations de l'HTC et des PST en fonction de l'âge gestationnel sont semblables à ceux de la POC. La PSM et le PP sont corrélés de façon linéaire à l'âge gestationnel. L'augmentation du PP avec l'âge gestationnel favorise le flux de liquide de l'espace intravasculaire vers l'espace extravasculaire au cours de la grossesse normale.

Mots-clés: Gradient PSM-POC, pression osmotique colloïde (POC), pression sanguine moyenne (PSM), protéines sériques totales (PST).

Bibliography

[1] Chesley, L. C., G. M. DUfFus: Posture and apparent plasma volume in late pregnancy. J. Obstet. and Gynaec. Brit. Cwlth. 78 (1971) 406

[2] DUNN, O.J., V. A. CLARK: Applied statistics: Analysis of variance and regression. John Willey and Sons, N.Y. (1974) 295

[3] HYTTEN, F. E.: Water storage in normal pregnancy. Int. J. Gynaec. Obstet. 8 (1970) 343

[4] HYTTEN, F.E., I. LEITH: The physiology of human pregnancy. Blackwell Scientific Publications (1971)

[5] LUND, C. J., J. C. DONOVA: Blood volume during pregnancy. Amer. J. Obstet. Gynec. 98 (1967) 393

[6] PIRANI, B. B. K., D. M. CAMPBELL, I. MCGILLIVRAY: Plasma volume in normal first pregnancy. J. Obstet. Gynaec. Brit. Cwlth. 80 (1973) 884

[7] ROBERTSON, F. G., G. A. CHEYNE: Plasma biochemistry in relation to oedema of pregnancy. J. Obstet. Gynaec. Brit. Cwlth. 79 (1972) 769

[8] STARLING, E. H.: On the absorption of fluids from the connective tissue spaces. J. Physiol. 19 (1896) 312
[9] STUDD, J.: The plasma proteins in pregnancy. Clin. Obstet. Gynecol. 2 (1975) 285

[10] WALTERS, W. A.W., Y.L. LIM: Blood volume hemodynamics in pregnancy. Clin. Obstet. Gynecol. 2 (1975) 301

[11] WU, P. Y. K., G. ROCKWELL, L. CHAN, S. WANG, V. UDANI: Colloid osmotic pressure in newborn infants: Variations with birthweight, gestational age, total serum solids and mean arterial pressure. Pediatrics 68 (1982) 814

Received March 15, 1983. Accepted April 19, 1983.

Paul Y.K. Wu, M.D. Women's Hospital, Rm L-919

Los Angeles County-USC Med. Ctr. 1240 N. Mission Road Los Angeles, CA 90033, USA 